\title{
わが国の最近 1 年間における教育心理学の研究動向と展望
}

\author{
発 達 部 門（児童期まで） \\ 乳幼児・児童期の研究動向 \\ 一乥こから見えてきたもの一
}

桂 田 恵美子

(関西学院大学)

A Review of Psychological Studies on Children in Infancy, Early and Middle Childhood: What We Can Learn from It

\author{
Emiko KATSURADA
}

(Kwansei Gakuin University)

This paper is a review of studies on children in infancy, early and middle-childhood, published in Japanese Journal of Educational Psychology, Japanese Journal of Developmental Psychology, Japanese Journal of Psychology, Japanese Psychological Review over the last year (from July 2013 to June 2014) and proceedings of the 56th annual meeting of the Japanese Association of Educational Psychology. Studies reviewed represented seven content areas : cognitive development, social cognition, social development, interactions between children and their mothers, studies on parents, studies on educational practice, and studies on developmental disability. My personal comments including suggestions about future research were added to each study. After reviewing those studies, I particularly addressed the importance of collaboration between researchers and school teachers in education-related field studies and the impact of emotion on cognitive process as a future research direction.

Key Words : young children, middle-aged children, cognitive development, social cognition, social development

本稿では 2013 年 7 月から 2014 年 6 月までに『教育心理学研究』『発達心理学研究』『心理学研究』 『Japanese Psychological Research』及び，『日本教育心理学会第 56 回総会発表論文集』に発表され た乳幼児・児童に関する研究論文，論文抄録を概観した。内容的に認知発達に関する研究，社会的認知 に関する研究, 社会性の発達に関する研究, 親と子の相互作用に関する研究, 親が研究対象となってい る研究，教育実践に関する研究，発達障害児に関する研究の 7 項目に分けられた。それぞれの研究結果 や研究手法について筆者の視点からコメントした。最後に, 教育現場と研究者との協力体制, 認知過程 における感情・情動の影響など，本稿で取り上げた研究論文から見えてきたことについて論じた。

キーワード : 乳幼児, 児童, 認知発達, 社会認知, 社会性の発達

はじめに

本年度は, 昨年度の『教育心理学年報』がカバーし
た以降，つまり 2013 年 7 月から 2014 年 6 月までに発 表された論文を概観した。昨年度にならい『教育心理 学研究』『発達心理学研究』『心理学研究』『Japanese 
Psychological Research』及び，『日本教育心理学会 第 56 回総会発表論文集』に発表され，かつ研究の対 象が乳児, 幼児, 児童である研究, 乳幼児・児童の親 が対象になっている研究を選択した。

一年間の研究動向ということなので, 研究のテーマ が同じ，あるいは似ているものをまとめ，それぞれの 研究論文に対して筆者の視点から展望も含めたコメン 卜を加えた。テーマは, 認知発達に関する研究, 社会 的認知に関する研究, 社会性の発達に関する研究, 親 と子の相互作用に関する研究, 親が研究対象となって いる研究，教育実践に関する研究，発達障害児に関す る研究の 7 項目に分けて整理し, その順番で述べてい く。

\section{認知発達に関する研究}

認知発達に関する研究は多義にわたるが，この分野 で同じあるいは類似のテーマのものは，ワーキングメ モリに関する研究と分配に関する研究であり，本稿で はそれらを取り上げた。

\section{ワーキングメモリに関する研究}

湯澤・渡辺・水口・森田・湯澤（2013）の研究はワー キングメモリの小さな子どもは学習遅延や発達障害の リスクを抱えることが明らかになっていることから， ワーキングメモリが相対的に小さい子どもたちの授業 での学習行動を観察した。小学校 1 年生 2 クラス 79 名を対象に，まず，ワーキングメモリアセスメントを 行いワーキングメモリが最も小さい子どもを各クラス 3 名選び, 合計 37 時間の授業時間の行動観察を行っ た。観察は主に授業に参加しているかどうかというこ とであり, 具体的には, 教師の指示に従っているか, 教師の板書を写しているか, 他の児童の発言を聞いて いるか，教師の説明（クラス全体に向けての発話）を聞い ているかについての行動観察である。また，半年後 (対象児が 2 年生になった時), 再び $1 \sim 2$ 時間の授業観 察を実施し，この時は，ワーキングメモリが平均的な 児童を各クラス 3 名選び, 授業での行動を比較検討し た。その結果，ワーキングメモリが相対的に小さい児 童は平均的な児童に比べて少なくとも 1 つ以上の教科 の授業での参加率が低かった。また，教科に関係なく， 他児の発言を聞いていない, 教師の全体に向けての説 明を聞いていないことが明らかとなった。更にこの研 究では, 観察対象児の挙手行動の観察からワーキング メモリが小さい児童に対する支援方法を提案し，その 支援方法がワーキングメモリの小さい児童だけでなく， 他の児童にも有効であることが教師との検討会の報告
で明らかにされている。

この研究で特に興味深かったのは，ワーキングメモ リアセスメント後に，観察対象となる児童を伝えると， いずれの児童も教師が以前から気になる子として認識 している子どもであったことである。これは, ワーキ ングメモリが小さいことは学習活動においてリスクを 抱えていることを支持するものである。ただ，気に なったのは，ワーキングメモリと IQ は関係があると 思われるが，この研究では IQ は統制されていない。 IQ も測定し，それを統制した上でワーキングメモリ が小さい児童を選ぶべきではないのかと疑問に思った。

もう一つのワーキングメモリに関する研究は渡辺・ 湯澤・水口（2014）によるものである。ワーキングメモ リには言語性と視空間性ワーキングメモリがあり，そ れぞれが算数の作問課題の問題解決とどの様に関連し ているのかを検討した。小学校 2 年生と 3 年生各 80 名を対象に絵と式を提示し, 絵を見て式に相当する作 問をつくらせた。結果は, 全体の数量で一部の数量が 判明した時残りの部分の数量を求める「求補場面」で は，言語性ワーキングメモリが高い子どもは低い子ど もよりも式と絵の両方に対応した解答が多かったが, 言語性ワーキングメモリが低い子どもは式と絵のどち らにも対応していな解答が多かった。しかし，視空間 性ワーキングメモリの高低によるこのような差はな かった。一方， 2 つの数量の違いを求める「求差場 面」では視空間性ワーキングメモリの高い子が低い子 よりも式と絵の両方に対応した解答が多く，視空間性 ワーキングメモリの低い子は式と絵のどちらにも対応 していない解答が多いという結果であった。つまり, 作問の求差場面と求補場面では言語性ワーキングメモ リと視空間性ワーキングメモリが違った働きをしてい ることが明らかになった。この結果から, 著者らは求 差場面あるいは求補場面の解答を困難とする児童には 違った支援アプローチが必要であるとしている。また， 学年差から, 言語性ワーキングメモリは 3 年生の方が 大きく, 視空間性ワーキングメモリには 2 年と 3 年の 差はそれほど大きくないことが示唆された。

この研究はワーキングメモリを細分化し，それぞれ の機能について明らかにしたものである。細分化され たワーキングメモリと学習における得意・不得意の関 連が明らかにされると，この研究が示唆しているよう に子どもに対する支援も異なるものとなり，より効果 的なものとなると思われる。今後は, 異なるワーキン グメモリの特徵を持つ子どもに対する異なる支援の効 果を明らかにしていく必要があるだろう。また，算数 
だけでなく，他の教科においても同様の結果が見られ るのかを検討することが望ましい。ワーキングメモリ の個人差と思考のパターンが明らかにされることによ り，児童に対する学習支援の効果も汎化されると思わ れる。

尚, 教育心理学会第 56 回総会では，このワーキン グメモリと発達障害に関するシンポジウムが行われて いる（湯澤・齋藤・河村・湯澤・無藤, 2014）。そこでは，あ る高等支援学校の職業支援についての実践事例の話題 提供もなされた。また, 藤本・山本・竹内・林 (2014) は，ワーキングメモリを鍛える教材「触覚版ジャンケ ンメモリ」を開発し，その効果を検証している。塾の 休咊時間を利用し， 5 人の小学生が， 5 ケ月から 9 ケ 月程度このジャンケンメモリを行い, その前後に「数 の逆唱」「音韻整列」のワーキングメモリ課題を実施 したところ，その得点が上昇していた。つまり，この 「触覚版ジャンケンメモリ」の効果が示された。しか し，被験者がたった 5 名であることやここで実施され たワーキングメモリ課題が上述の湯澤・渡辺ら (2013) の高い妥当性が示されたワーキングメモリアセスメン 卜と同等なものなのかわからないので, その効果にも 疑問が残る。

\section{分配に関する研究}

津々（2013a）は自身の先行研究に基づき, 均等分配 方略 (一巡方略, 数巡方略, 空皿方略) と報酬分配パターン の関係を検討する実験を実施した。対象は 5 歳児 61 名であった。課題は， 2 人の登場人物が星をつくり, その作業量がそれぞれ違う（3対1）という物語を紙芝 居で提示し，ご褒美にアメがもらえるとことでアメを 幼児に与え，一番良いと思うように 2 人の登場人物に 分配することであった。物語は, 総作業量が 12 と 16 の 2 種類あった。また, 総作業量とアメの数が同じ等 条件, 総作業量より少ない少条件, 総作業量よりも多 い多条件の 3 条件が設定された。つまり，一人の幼児 は 6 つの課題を行った。結果, 総報酬量が少ない条件 では，一巡方略で作業量にかかわらず同等に分配する 平等分配が多く見られた。一方，多条件においては， 平等分配では数巡方略を，作業量に応じて分配する公 平分配では一巡方略を用いる幼児が多かった。

一巡方略または数巡方略を使うかは, 幼児の処理で きる数によるのだと思われる。実際, この実験でも, アメが 4 個の場合と 8 個の場合（ぞちらも少条件）では, 平等分配をした幼児が圧倒的に多かったが，4個の場 合は一巡方略が多く，8個の場合は数巡方略が多かっ たという結果が出ている。興味深いのは, 総報酬量の
多寡により，分配パターンが異なるという結果である。 これは，5歳児は作業量の差によって報酬に差をつけ るという公平分配を知ってはいるが, 報酬量が少ない 時にはそのような差をつけずに平等に分けるというこ とを行っている。同じような状況で大人だとどのよう な分配をするのであろうか。大人については一切触れ られていないので, あくまでも推測であるが， 5 歳児 と同じような反応ではないかと思われる。そうだとす ると, 5 歳児の反応は, もしかしたら, 大人 (母親や 幼稚園の先生) の反応を見ていて獲得されたものかもし れないと考える。今後, これらの分配パターンの発達 的変化を見るのも興味深いと思う。

上記の研究においても興味深い結果として述べたが, 総報酬量が少ない時には, ほとんどの 5 歳児が平等分 配を行うことが明らかになった。また，幼児に理由を 尋ねると「分け前が少ないと可哀想」のような感情に 左右されていると思われる答えが多かった。そこで引 き続き, 津々 (2013b) は, 少条件での平等分配は感情 に影響された結果なのかどうかを調べた。この実験で は，67名の 5 歳児が対象となった。実験の手続きな どは上述の実験（津々, 2013a）とほほ同じであるが, こ こでは, 総作業量は 12 だけとし, 紙芝居における作 業量の少なかった登場人物を泣き顔にした場面を設け たことが異なっている。つまり，ここでも幼児は 6 条 件 (ニュートラル場面と泣き顔場面 $\mathrm{x} 3$ 総報酬量) の課題を 行なった。また, 幼児は最後に作業量の少ない人物が なぜ泣いているのかを尋ねられた。結果, ほとんどの 幼児は泣いている理由を適切に答えられた。また， ニュートラル場面と同様に, 泣き顔場面に扔いても少 条件 (総報酬量 4 個) で，ほとんどの幼児 (87.5\%) が平 等分配を行った。一方, 多条件 (総報酬量 20 個) で平 等配分を行ったのは $68.8 \%$ で, この差は有意傾向で あった。この実験で示された結果は, 泣き顔であるか どうかは分配パターンには影響せず, 影響するのは総 報酬量が多いか少ないかということであった。この結 果は大変興味深い。一般的に幼児の感情発達は認知的 発達より早いとされているので, 幼児は感情に影響さ れ, 泣いている人物に多く分配するという逆転分配が 多く見られるのではないかと予測したが，5歳児で あっても感情に振り回されることなく, 平等分配を行 なっていた。ここでもまた，果たして大人はどのよう な分配を行うのであろうか疑問に思った。大人の方が かえって感情に影響される割合は高いかもしれない。 大人との比較も今後是非して欲しい。 


\section{社会的認知に関する研究}

社会的認知としては, 乳児の顔パターンや顔の表情 の認知に関する研究や心の理論に関する研究を取りあ げた。

\section{顔パターン, 表情に関する研究}

乳児が顔を好んで見るということは良く知られてい るが，Ichikawa, Tsuruhara, Kanazawa, \& Yamaguchi（2013）は，それは乳児が単に顔パターンが上部に より多くのパーツがある top-heavy パターンを好む からなのかを明らかにするために選好注視法を用いた 実験を行なった。また, 顔が好まれるのは, 顔特有の 動きによるものなのか, それともどのような動きでも 良いのかについても明らかにすることを目的としてい る。前者の目的を遂行するために実験 1 を行った。こ こでは，2 2 月児と 3 ケ月児各 8 名の合計 16 名を対 象に，2 種類の幾何学的なパターン（3つの四角を顔パ ターンに並べたものと 3 つの四角を上部に一列に並べたもの) を静条件と動条件に分けて提示した。静条件は 2 種類 のパターンを動かない状態で提示し, 動条件は 3 つの 四角を 250 ミリ秒のスピードで垂直に縮めて行き，拡 張して元に戻るという動きのある状態で提示した。動 条件においては，まっすぐな状態と逆にした状態で提 示した。その結果，乳児は動きのある方を好み，その 条件下ではまっすぐな状態の方を好んだ。実験 2 では, 別の $2 \sim 3$ ケ月の乳児 8 名を対象に, 動条件での動き を顔特有の動きではなくするために，四角が水平に縮 んで元に戻るという動きで提示した。結果は実験 1 と 同じであった。つまり，乳児は動きのある方を好むが， それが顔のような動きでなくてもよいという結果で あった。 2 〜 3 月の乳児にとっては顔のように並べ られたパーツが動くこと自体に興味をそそられよく見 るということであった。しかし，論文中に示された動 きの図によると，実験 2 のアニメーションは顔特有の 動きではないとされているが，確かに実験 1 のアニ メーションの方が顔パターンに近い動きであると思う が，実験 2 の方も顔の動きのようにも見える。顔特有 ではないパターンの提示には, パーツ同士が離れたり くつついたりなど，明らかに顔の動きではない動きを 提示する方が良かったのではないかと思われる。この 研究結果からは, この年齢の乳児が単に動きを好むの か顔特有の動きを好むのかに関しては疑問が残る。

Ichikawa \& Yamaguchi（2014）は乳児が微妙な表 情を認知できるのかどうかを検証した。対象は 32 名 の生後 $6 \sim 7$ ケ月の乳児で, 静条件と動条件の下で実
験を行っている。静条件では, 微妙に怒った表情が 1200 ミリ秒提示され, 動条件では, 中性的表情に続 き微妙に怒った表情がそれぞれ 600 ミリ秒ずつ提示さ れた。この実験では familiarization-novelty 選好法 が使われ, pre- \& post-familiarization を含む 3 段階 で構成されている。結果，静条件で微妙な怒りの表情 が認知されたが, 動条件では認知されなかった。著者 らの別の実験では, 喜びの表情に関して全く逆の結果 が出ている。つまり, 微妙な喜びの表情は動条件で認 知され，静条件では認知されなかった。これらの結果 を総合して, 著者らは怒りの表情を読み取ることは危 険な状況を認知することに役立ち，それ故に，乳児は 微妙な喜びの表情よりも怒りの表情に対して敏感なの だろうと考察している。また，動条件で微妙な怒りの 表情が認知されなかったのは, 乳児の普段の生活にお いて，徐々に怒りが表出されるという経験がほとんど ないからだろうと考察している。確かに，一般的に乳 児期において，怒りの表出は見ることはあっても，そ れが徐々に表出するのを見ることはほとんどないであ ろう。しかし，怒りの表情に敏感であるのであれば， このような微妙な変化をも認知しても良さそうである。 今後, より経験豊富な年長の子どもでの実験によって, この点を明らかにしていく必要がある。

上記二つの研究は実験内容や手法は違うものの, 乳 児の人の顔に関する認知という点において共通してい る。これらの結果から，生後間もない乳児にとっては， 動きがより視覚的注意を引くことは明らかである。し かし, 微妙な怒りの表情は動きがある方が注意を引か ない結果であった。Ichikawa ら（2013）のパターンの 動きも笑顔に見える動きであったので，もしかしたら， 表情によって, 動きが与える影響が異なるのかもしれ ないと思った。今後，色々な表情での実験が望まれる。 表情に関する研究としては，もう一つ，枡田 （2014）の幼児の感情の理解と表情表現に関する研究 がある。この研究では, 幼稚園の年中児 23 名と年長 児 21 名に対して，感情を表す短い文章を読み聞かせ， 主人公の気持ちを問うラベリング課題，その主人公の 表情を描く描画課題, その主人公が各感情の時どのよ うな表情をするか表現してもらう表情表現課題を行っ た。ここで用いられた感情は悲しみ, 驚き, 喜び, 怒 り, 恐れの 5 種類であった。感情理解を問うラベリン グ課題においては, 年中児よりも年長児の得点が高く, 感情別では, 喜び, 悲しみ, 恐れの得点が高く, それ らの感情は正確に理解していたことになる。描画課題 と表情表現課題では，学齢間による差はなかったが， 
描画課題では, 喜びと悲しみの得点が高く, 表情表現 課題では喜びと驚きの得点が高かった。また, 各課題 の関連では，描画課題と表情表現課題は有意傾向の相 関が見られたが，ラベリング課題との相関は見られな かった。

この研究結果から, 幼児期において, 怒りの感情理 解や表現が難しいことがわかる。これは Ichikawa \& Yamaguchi（2014）の乳児が微妙な怒りの表情に対し てより敏感であるという結果と相反する。著者は怒り 感情理解得点が低かったという結果は先行研究の結果 と異なることを認めており，それはこの研究で使われ た怒りの物語がわかりにくかった為であると説明して いる。しかし, Ichikawa \& Yamaguchi (2014) でも 述べられていたように，怒りは喜びや悲しみに比べて， 乳幼児の毎日の生活の中で経験する頻度は低いと考元 られ，また，社会化において怒りの表出は抑制される 傾向にあるため, 怒りの感情理解や表出の困難につな がっている可能性もある。怒りの感情理解に関しては 更なる研究が望まれる。また, 感情理解を測定するラ ベリング課題と表現課題の相関がなかったことや，表 現課題では年長児で個人差が大きかったことから，年 長児は照れを感じて表情表現を抑制する可能性がある としているが，そうなると，今後，より良い方法を考 えなくてはならないことになる。

\section{心の理論に関する研究}

東山（2014）は，心的状態語の使用量と心の理論の 関連を 5 〜 歳児とその母親 53 組を対象に検証した。 心的状態語の使用量の測定は，母子に図版を提示し， 協力してストーリーを作成してもらい，その場面の分 析から評定した。結果, 部分的には心的状態語の使用 と心の理論の関連は見られるが, 相関は強いものでな く, 一貫性もないことから, 海外の研究結果とは異な り，心的状態語の使用量から心の理論を予測すること は難しいと結論づけている。心の理論の発達には, そ れまでの相互作用の積み重ねが重要であると思われる ので，心的状態語の使用量に関しては，この一時点で の測定で十分なのか，また，母親のみとの相互作用で 十分なのか疑問である。もっと，長期間の観察，母親 だけでなく, 子どもの周囲にいる人たちとのやり取り をも観察し，分析すべきであろうと思う。

佐藤・実藤（2013）は，心の理論の獲得を測定する通 常の誤信念課題に驚きを喚起する事象（物体消失・出現 マジック）を導入することによって子どもの誤信念課 題に扔ける正答率が高まるかどうかを検証した。対象 となったのは保育園の 3 歳児，4歳児クラス合計 69
名であった。対象児は，このマジックを含んだ非合理 的物体入替え課題, 従来の誤信念課題である合理的物 体入替え課題とスマーティ課題の 3 つの課題を行った。 非合理的物体入替え課題では, 子どもの目の前でエル モのパペットがカードを鍋に入れて去った後, 鍋の蓋 を開けてみると，中には紙製の花が入っているという マジックを見せた後に蓋をして，「エルモは鍋の中に 何が入っていると思うかな？」という他者信念質問を する。他に，鍋の蓋を開ける前は対象児は何が入って いると思っていたかを問う自己信念質問と今鍋に何が 入っているかを問う現実質問の合計 3 つの質問が各対 象児になされた。その結果, マジックを含んだ非合理 的物体入替元課題に扔いて他の課題よりも他者信念質 問の正答率が有意に高かった。また，自己信念質問に おいても, 非合理的物体入替え課題の正答率はスマー ティ課題の正答率よりも有意に高かった。

心の理論に関する研究としては, 上述の東山 (2014) の研究の様に, 心の理論と他の変数との関連 を見る研究が多いなか, この研究は誤信念課題におけ る幼児の認知に焦点を当てており, 驚きを喚起するこ とを含んだ誤信念課題を作成し実施して，そのような 驚きが他者の視点を正しく推測することを促進すると いう結果を示したことは大変興味深い。この驚きには 最初に入れた物の想起が含まれ, それ故に, 驚きの前 後関係が明確化され，驚きを経験していない者(この 研究ではエルモ）は驚きの後の物は知らないという認知 から正答率が上がったのではないかと考えられる。著 者らは考察に扔いて, 本研究の結果は従来の誤信念課 題のパーフォーマンスが子どもの誤信念を表象し，そ れに基づいて推論する能力の有無を反映しているもの ではないことを強く示唆していると述べている。確か に, 従来の誤信念課題は, 本研究の驚きを含めた課題 に比べると, 誤信念の表象を導き難いとは言えると思 うが, 従来の誤信念課題を否定しきれるのかは疑問で ある。

古見 (2013) は，心の理論に関するこれまでの議論 から，心の理論をも含むより包括的概念であるマイン ドリーディングという言葉を使い研究を進めている。 この研究はすでに成人において見られたロールプレイ ングのマインドリーディングに及ぼす効果が児童期の 子どもたちにも見られるのかを検討したものである。 この研究での対象は小学校 $3 \cdot 4 \cdot 5$ 年生合計 46 名と 大学生 40 名であった。小学生には二次的誤信念課題, うそと皮肉の区別課題, 責任性の理解課題の 3 つの心 の理解課題が行われた。これら 3 つの課題全てに正答 
した者を児童-高群とし，一つでも誤答のあった者を 児童-低群として, 成人 (大学生) と比較した。児童と 成人どちらにも施行した課題はコミュニケーション課 題と呼ばれ，店長が店員（ウサギ）に棚の中の物を取 るように伝え店員が物を取るというゲームである。店 長と店員は見えている物がちがうので，正答するには ウサギの視点にたって答えなければならない設定に なっている。つまり，コミュニケーション課題とは なっているが，マインドリーディング能力を測定して いると言える。この課題では, 対象者は事前にロール プレイを実施した群としなかった群にランダムに振り 分けられ, その誤答率を比較している。結果, ロール プレイ群がロールプレイなし群よりも課題における誤 答率が低かった。つまり，ロールプレイの効果が児童 においても確認された。また，この課題における誤答 率は心の理解課題とも関連があり, 児童-低群, 高群, 成人の順で高かった。

ロールプレイの効果に関して，著者はどのような側 面がプラスの影響を及ぼしたのかは未確認であるとし ながらも，ロールプレイで店員のウサギが間違うとい う経験もしているので, そこで喚起されたネガティブ 情動の経験が影響している可能性を挙げている。この 説明は佐藤・実藤（2013）の驚きを含んだ誤信念課題に おいて正答率が高くなるという結果の説明にもなるの ではないかと思われる。佐藤・実藤の実験においても， 驚きという情動を経験している。この経験の有無が認 知に影響している可能性があり, 今後, 認知とその認 知過程で経験する情動に関する更なる研究が望まれる。

\section{社会性の発達に関する研究}

社会性の発達は広範囲にわたるので, ここでは社会 性そのものを取り扱った研究, 感情 (情動) 理解・表 出, 規範行動, 集団排除に関する研究を取りあげた。

眞榮城・梅崎・前川・則定・上長・田仲・酒井 (2014) は, 子どもの社会性 (コンピテンス : 自己有能感と社会的受 容感) の発達を見るために縦断研究を行っている。親 のしつけとの関連において年長のきょうだいも含めて 分析した。その結果，子どものコンピテンスは 3 歳時 よりも 4 歳時に高くなり, 親のしつけとの正の相関が 見られ, 親の養育態度がコンピテンスを高めることが 示された。しかし，偏相関の結果は，同時期による相 関のみであり， 3 歳時の親のしつけと 4 歳時の子ども のコンピテンスの関連は出ておらず，因果関係は言え ないのではないかと思われる。また，子どものコンピ テンスが親の評定によるもののみであることも問題点
であろう。この研究チームは同様のデー夕を使い, 子 どもの習い事とコンピテンスの関連も調査しているが, 明確な結果は出ていない（梅崎・眞榮城・前川・則定・上長・ 田仲・酒井・酒井, 2014)。

感情（情動）理解・表出に関する研究では, 近藤・林 （2014）が感情音声の理解と表出について 5 歳児 3 名, 7 歳児 4 名に実験を行っている。喜び，怒り，悲しみ, 驚き, 平静の 5 感情について, 表出課題 (それぞれの感 情を込めて無意味語を発話する), 模倣課題（音声刺激を模倣 する), 理解課題（音声刺激がどの感情が込められていたかを 推測する) を行った。理解課題において, 怒りや悲し みの感情理解では 5 歳児と 7 歳児は同得点であったが, 表出課題においては個人差が大きく，7歳児でもでき ない者が多かった。非常に興味深い実験であるが，発 達を見るためには, もう少し年齢を下げた子どもも含 めて欲しい。また, 著者らも述べているょうに, 人数 が少ないので, もっと多くの子どもへの実験が必要で ある。

平川 (2014) は怒りの主張的表出が幼児期・児童期に おいてどのように発達するのかを明らかにするために 研究を行った。対象は幼稚園に通う年中・年長児と小 学 1 年生であった。対象児には絵カードを使い拈話を 提示し, 言語表出ができない時 (「やめて」と言えない時) と言語表出ができる時 (「やめて」と言う時) で, どのよ うな表情をするかを 3 つの表情カードの中から選ばせ た。結果, 言語表出ができない時は年齢が上がるにつ れて, 怒りの表出が強かったが, 言語表出ができる時 は年齢による差はなかった。この結果から，年中児は 怒りを表出するのは良くないという規範にしばられて， その表出が抑制されるが，年齢が上がるにつれてバラ ンスを取りながら情動表出をするようになると著者は 考察している。

この研究結果は幼児期から言語的表出と感情の表出 の関係性を理解できるようになることを示している。 怒りの情動表出は下手すると攻撃性につながるもので あるが，言語による自己主張を教えることによって， 怒りの表出は少なくなると考えられ, 幼児期からの言 語主張教育の重要性を示唆している。この研究では, 子どもに状況を説明し答えを求めるという手法を取っ ているが，これが現実の場面での実際の行動とどのく らいの整合性があるのかということに疑問を持った。 今後は実際の行動において怒りの主張的表出がどのよ うに起こっているのかをも研究して欲しいと思う。

怒りと社会的スキルの因果関係の調査研究もある。 寺坂・下田（2014）は，小学生を対象に学校での怒り多 
次元尺度と社会的スキル尺度を用いて，10月と 12 月 の 2 時点で測定し，その関連を調査した。その結果， 怒りの中でも, 敵意が後の社会スキル, 特に仲間強化 と規律性スキルを低めることが示された。怒り尺度の 項目を確認できないので，はっきりしたことは言えな いが，敵意において関連が見られたことから，怒りの 表出と言うょりも，内に秘めた怒りなのではないかと 思われる。いずれにせよ，怒りは社会的スキルにおい て良い結果をもたらさないことは明らかなようである。 規範行動に関する研究は山田・小泉・中山・宮原 （2013）があげられる。彼らはまず，小・中学生の規範 行動を簡便に測定できる尺度を作成し，その尺度を用 いて小学 3 年生から中学 3 年生までの児童 2,774 名を 対象にその発達的変化を調查した。作成された尺度は 対人間での望ましい行動，対人間で遵守すべき行動， 個人として遵守すべき行動の 3 因子 19 項目から構成 され，併存的妥当性が確認された。発達的変化につい ては，いずれの下位尺度においても学年が上がるにつ れて規範行動が減少することが明らかにされた。また， 男子の規範行動は女子よりも早い時期 (小学校中学年 頃）に減少することが明らかにされた。

この研究で明らかにされた規範行動の発達から, 平 川（2014）が考察していたように幼稚園児ではより規 範にしばられているのではないかと推測されるが，行 動面となると必ずしも幼い方が規範行動ができるとも 限らない。いつ頃から規範行動ができるようになるの かは興味のある研究テーマであり，年齢をもっと低め て幼稚園児からの規範行動の発達を明らかにして欲し いと思う。

規範行動にも関連があると思われる集団排除基準の 発達的変化を取り扱った研究がある。長谷川 (2014) は, 集団から排除される 5 種類の他者（暴力的な人, 手 づかみで食事をする人, 髪を緑色染めている人, グループのメ ンバーと気が合わない人, 毎日黄色い服を着る人) を設定し, 集団のメンバーで遊びに行く私的集団と授業の課題で 班として商店街に調查に行くという公的集団を設定し て，対象者に場面を提示し，その人を排除すべきか， その理由，その人が変わるべきだと思うか等の質問に 答えてもらう調查を行った。対象者は小学 4 年生, 6 年生, 中学 2 年生, 大学生合計 255 名であった。分析 の結果，排除するかどうかの得点には学年差は見られ なかったが，年齢が上がるにつれて，排除される人の 特徵を区別して排除の判断をしていることが明らかに なった。また，中学生を除いた全ての学年で公的集団 の方が私的集団よりも排除を認めないことが明らかに
された。更に，年齢が上がるに従い排除する人の特徵 の変容を求めなくなるということも明らかにされた。 山田ら（2013）の規範行動の研究では年齢が上がる につれて規範行動が減少するということであったので， 他者排除というのも反規範行動に含まれるので, 特に 公的集団における他者排除においては発達的変化が見 られると予測したが, 排除得点には発達的変化は見ら れなかった。この研究では, 排除される他者に特異な 特徴が含まれており, その点で規範行動とは違った意 味になるのかもしれない。ただ，年少者では排除され る他者の特徵をあまり細分化して排除の判断を決めて いないという意味では, 規範的と言えるのかもしれな い。つまり，山田ら（2013）の結果と共通する。

集団排除に関連して, 児童の仲間外れに関する研究 もある。西野（2014）は日常ストレッサーが仲間外れ を促進するが，居場所感がその関連を緩衝するという 仮説モデルを検討した。小学校 4 ・ 5 年生 604 名を対 象に質問紙調查を行い分析した。結果, 4 年生男子に おいてのみ日常ストレッサーが仲間外れを促進するこ とが示され， 5 年生男子においてのみ居場所感が仲間 外れを抑制することが示された。著者は, 全体的には 仮説モデルは支持されなかったが，可能性は一部確認 されたとしている。しかし，女子においては全く結果 が出ておらず，男女別のモデルを考える必要があるの ではないかと思われる。

松本（2014）は排除の反対の概念である友人の受容 性に着目し, 調査研究を行っている。小学校 $4 \cdot 6$ 年 生 342 名を対象に個人の受容性, 友人グループの排他 性，他者との関わり経験，個人の性格について質問紙 調査を行った。結果，女子の方が男子ょりも，関わり 経験高群が低群よりも受容性が高いことが明らかと なった。また，友人グループの排他性や個人の協調性 や外交性が友人の受容性に関連していることが示され た。しかし, この研究では 4 年生と 6 年生の発達的な 変化は見られなかった。

この研究結果を踏まえると，上述の長谷川 (2014) の研究においても, 個人の性格や他者との関わり経験 などを統制変数として入れることによって違った結果 が得られるかもしれないと考えた。

\section{親と子の相互作用に関する研究}

親と子の相互作用を観察した研究は 4 篇あり, どれ も乳児と母親の相互作用を観察している。ここでは, その 4 篇について見ていく。

石島・根ヶ山（2013）は，母子のくすぐり遊びに注目 
し，その発達的変化を観察した。対象は生後約 5 ケ月 の女児と母親であり，3 月月間にわたって観察した事 例研究である。ここでは，普段の遊びの中に，好きな タイミングでくすぐり遊びをするように依頼している。 録画したくすぐり遊びの相互作用を分析した結果，母 親は初め通常のくすぐり行動を行っているが，生後 5 ケ月 26 日でくすぐりの焦らし行動が起こり, その 後この行動は増加傾向にあった。くすぐり遊びの成功 事例における諸行動の生起夕イミングの図によると, 母親のくすぐりの焦らし行動は実際にまだくすぐって いるわけではないのに乳児のくすぐったがり行動を引 き起こしている。そして，母親はその行動を一度やめ， 再びくすぐり焦らし行動を行い, その後実際にくすぐ るという行動に移つている。くすぐり焦らし行動の最 中は乳児はどちらかというとくすぐり刺激源，つまり， 母親の指先を見ているが，母親が一旦その行動を止め ると母親の顔を見ているなど，このくすぐり遊びにお いて母子のコミュニケーションが起こっていることが 分かる。著者らは, このようなくすぐり遊びにおける 相互作用が相手の心的状態を理解する基盤的な体験と なっていると考察している。しかし，くすぐり遊びは あくまでも遊びであり，この研究では必ずくすぐり遊 びを入れるよう要請して発生している。自然発生的に はいつ頃から, どのくらいの頻度でくすぐり遊びが行 われているのか, そしていつ頃この遊びは見られなく なるのかなどが明らかではないので，上述の考察には 疑問の余地もある。また，遊びであるので，より刺激 を強くするために子どもの予測を裏切るような行動パ ターンを見せる母親もいるかもしれない。そうなると， くすぐり遊びが果たして乳児が相手の心的状態を理解 する基盤になっているのだろうか疑問である。しかし， このような遊びにおける行動パターンが毎日の養育に おける行動パターンにも反映されるとなると, 著者ら の考察は領ける。今後, くすぐり遊びにおける行動パ ターンと養育における行動パターンの関連なども検討 して欲しいと思う。

蒲谷 (2013) は，母親が子どもの内的な状態に共感 的に対応し，フィードバックを行う調律的応答が母親 自身の内的作業モデルによってどのように異なるのか, また，子どもの気質にも注目し，どのような組み合わ せで, 調律的応答が行われやすいのかを検証した。対 象は 38 組の生後 $5 \sim 9$ ケ月の乳児と母親であった。 相互作用は 5 分間のおもちゃを交えた自由遊びの間に 5 分間の準母子分離場面を含めた 15 分間で観察され た。母親の内的作業モデルは ECR-GO で, 子どもの
気質は RITQ 日本語版で判定された。分析の結果, 愛着安定型の母親は子どものネガティブな情動表出に 対して笑顔を伴った心境言及をするという応答パター ンが多く見られた。一方, 愛着不安定型の母親は無表 情のまま単純応答するとか, 無言で笑顔を浮かべるな どの応答パターンが見られた。また, 子どもの気質と の組み合わせでは，気質的にむずかりやすい場合のみ であるが，回避傾向の高い母親ほど子どものネガティ ブな情動表出に対して笑顔を伴った心境言及をしない という結果が得られた。

母親の愛着を ECR-GO で測定することに対しては， 成人の愛着測定具として世界的に用いられている AAI を使うべきではないかという議論が出てくると ころである。しかし，AAI は実施，判定が煩雑な上， 訓練を受けて認定された者のみ使用可能という制約も あり，使用が困難であるため， ECR-GO のような質 問紙を使用するのも理解できるが, ECR-GO で測定 される愛着はパーソナリティ的側面が強く, AAI で 測定される生育歴から明らかにされる無意識的なもの も含む愛着とは異なることを頭に入れたうえでこの結 果を解釈すべきであろう。いずれにせよ, 安定した対 人関係を形成できる特性を持つ母親は自分の子が泣い たりした時などでも, 笑って子どもの気持ちを汲み取 り，子どもにフィードバックするという応答パターン が多く見られ, 回避やとらわれ傾向の強い母親とは 違った応答パターンであったことは興味深い結果であ る。著者は, 愛着の世代間伝達を踏まえて, このよう な安定型母親の調律的応答がその安定型の子どもの共 感性の発達に寄与しているのではないかと考察してい る。この考察は理論的には納得のいくものであるが, 是非とも実証研究にて明らかにして欲しい。

蒲谷（2014）はまた，母親の調律的応答と「子ども 表象」との関連についても研究している。この研究で の対象者は生後 5-11ヶ月の乳児とその母親 40 組であ る。調律的応答に関しては上述の研究と同様相互作用 の行動観察から判定し，「子ども表象」に関しては子 どもが生後 3 - 9 ケ月時に実施したWMCIの回答か ら「子ども表象」産出困難感を測定した。結果，「子 ども表象」産出中位群の母親は他の群の母親よりも子 どものネガティブな情動表出に対して乳児の内面を映 し出す心境言及を行いやすい, つまり, 調律的応答を 行いやすいことが明らかになった。著者はこの中位群 の母親がどのようなワーキングモデルを持っているの か今後より詳細な吟味が必要と述べている。抄録のた め, この「子ども表象」産出困難感が何を表している 
のかよくわからないので，コメントのしようがないの であるが，単に「子ども表象」産出が容易であれば良 いというものでもないようである。

上記の蒲谷 $(2013 ; 2014)$ の研究では, 乳児のネガ ティブな情動表出に対する母親の反応を観察していた が，岡本・菅野・東海林・高橋・八木下・青木・石川 他（2014）は，乳児のポジティブな情動表出も含む母 親とのコミュニケーションに打いて，母親の代弁に注 目して観察している。この研究では 12 組の母子を, 出産 0 ケ月から 15 ケ月まで 3 ケ月毎に観察を行い, そのデー夕を分析した。その結果, 母親の代弁の頻度 は 9 ケ月頃にピークとなり，12ヶ月時には減少すると いう発達的変化が明らかとなった。また，観察結果か ら代弁の機能を「子どもに合わせた代弁」「子どもを 方向づける代弁」「状況への働きかけとしての代弁」 「親の解釈補助としての代弁」の 4 つに分類している。 前者二つは蒲谷 $(2013 ; 2014)$ の研究における調律的応 答に通じるものがある。つまり，母親はまだしゃべら ない乳児に対して，ネガティブな場面だけでなく， 様々な場面に扔いて子どもの発声や動きからその意図 を読み取って言及するという調律的応答を行っている ことが分かる。また, 岡本ら（2014）は後者二つの代 弁は親自身のための代弁であり, 親の情緒調整的な機 能を持つとしている。

蒲谷 (2013) の研究と岡本ら（2014）の研究を読んで, この代弁という行為にも母親の愛着特性の違いによる 差異があるのではないかと考える。また，子どもの安 定した愛着形成には母親の敏感な反応, 適切な応答が 影響している (Ainsworth, Blehar, Waters, \& Wall, 1978) とされているので, こうした母親の代弁は敏感な反応, 応答性に通じるものがあり, 子どもの愛着形成にも影 響するのではないかと考える。また，代弁が情緒調整 的な機能を持つのであれば, 他の養育行動にも関連し てくると考えられ, 今後, この代弁の個人差に注目し た研究へと発展していくことを期待している。

\section{親が研究対象となっている研究}

子どもの環境の一つとして親の影響は多大なもので あるので, 乳幼児・児童を持つ親を対象とした研究を 取り上げ考察した。親を主な研究対象とした研究は 3 篇あり，その内 1 篇は知的障害児を持つ親を対象とし たものである。また，1篇は子どもをも調查対象に含 め, 子どもへの影響を検討している。

子どもを含めた研究は, 本島 (2013) の研究である が，本島は家族の表出性に注目し，それが子どもの問
題行動にどのように影響してくるのかを検討した。家 族の表出性とは家族内の言語的・非言語的な主なス夕 イルで，ポジティブかネガティブで測定される。対象 となったのは 49 組の乳児を持つ母親で, 家族の表出 性, 母親のうつ, 乳児との相互作用から母親の敏感性, そして子どもの問題行動は CBCL で測定された。そ れぞれの変数は時期をずらして測定され（家族の表出性 は子どもが 9 ケ月時, 母親のうつ, 敏感性は 18 r月時, 子どもの問 題行動は30ケ月時に測定) 因果関係を検討している。分 析の結果, 家族のポジティブな表出性は母親の敏感性 に，ネガティブな表出性は母親のうつに影響を与え， 母親の敏感性は子どもの問題行動には影響していな かったが，母親の抑うつは子どもの内在化，外在化問 題に影響していた。この結果から, 家族の表出性は子 どもの問題行動に直接影響はしていないものの, 母親 の抑うつ症状を介して子どもの問題に影響していると 結論づけている。

この研究では, それぞれの変数の測定時期をずらし て, 因果関係を明確にしていることが評価できると思 う。しかし, 著者自身も今後の課題として述べている が，家族の表出性であるにもかかわらず，母親のみの 評定であり, 父親の評定も含めて, より客観的な家族 の表出性にすべきではなかったかと思う。また, 家族 の表出性の関連として母親の抑うつと敏感性を取り上 げているが，子どもの問題行動に関連があると思われ る母親の養育行動なども取り上げ家族の表出性との関 連を検討して欲しい。

加藤・黒澤・神谷 (2014) はリサーチ専門データベー スに登録している父親・母親合計 1,000 名を対象に, 「夫婦ペアレンティング調整尺度」の妥当性・信頼性 を検証している。元々の尺度は, 海外で作成された “Parenting Regulation Inventory”で，母親による 父親の子育てに従事することへの促進と抑制の程度を 測定するものである。それを翻訳，修正し，母親だけ でなく父親も回答できるように日本語版を作成した。 日本語版尺度は促進と批判の 2 因子から成る全 16 項 目の尺度が作成された。その他に育児に扔ける協同感 や夫婦関係満足度, 父親の子育て関与度を測定し, 妥 当性を検討している。その結果, それぞれの尺度は中 程度から弱い有意な相関を示し妥当性が確認された。 内的整合性も分析し, 信頼性も確認された。また, こ の研究では, 末子の年齢を $0-5$ 歳 (乳幼児期), 6-11 歳 (児童期)，12-17 歳 (思春期)，18-21 歳（青年期）の 4 群に分け, 地域も 5 群に分け均等割付をしている。 そして, 夫婦のペアレンティング調整（促進と批判）が 
子どもの年齢によってどのように違うのかを検討して いる。その結果，母親の促進行動は思春期以降有意に 減少し, 批判行動も乳幼児期に比べて青年期では有意 に少なかった。父親に関しては，促進行動は母親と同 じであったが，批判行動は子どもの年歯による有意な 差はなかった。更に，母親の性役割観との関連も見て いるが，批判行動と有意な負の相関を示したが，相関 係数は非常に低かった。

尺度作成において，このような地域性に偏りもない 大規模調査を実施することは望ましいことと思われる。 しかし，著者らも述べているように，ここで使用され ているインターネット調査の登録者というサンプルの 偏りがあるかもしれない。この研究では，末子が青年 期の親も含んでいるが，果たしてそこまで入れる必要 があったのかと思う。ペアレンティングの内容が，乳 幼児期と青年期では全く違ったものであるので，乳幼 児期・児童期に絞り，より細かい子どもの年齢分類に よる差異を見る方が意義があったのではないかと思う。 また，子どもの年齢を絞ることにより，この研究では 明らかにされなかった性役割観との関連も明らかにな る可能性がある。なぜなら，日本では，まだまだ専業 主婦が多く，子どもが小さい内は，子育ては母親の役 割という性役割分業がはっきりしているので，母親の 性役割観がペアレンティング調整行動（促進と抑制）に 影響してくるのは，子どもが小さい時に限られるので はないかと考えるからである。いずれにせよ，著者ら も言っているように，今後はこの尺度を使い，夫婦間 のズレなどに着目した研究が興味深いと思われる。

Kono \& Mearns (2013) の研究は知的障害児を持つ 親がストレスにどのようにコーピングをしているのか， その親たちの中でも, ある行動や認識に従事すること はネガティブなムードを緩和するという信念（negative mood regulation expectancies ; NMRE) を持つ親は子 どもの障害の程度にかかわらずよりアクティブなコー ピングをしていて，苦痛も少ないのではないかという 仮説を立てて検証した。知的障害児を持つ親 106 名に 対してNMRE，コーピング方法，苦痛症状に関する 質問紙調査を実施した。分析の結果，対象となった親 たちの苦痛症状得点は低く, あまり苦痛を感じておら ず，親の年歯が高いほど苦痛症状得点が低いという負 の相関が見られた。また，NMRE得点も苦痛症状得 点と負の相関が示された。しかし，NMRE得点は コーピングとは何の関連もなかった。

知的障害児を抱える親ということで，高い苦痛症状 得点を予想していたが，結果としてはあまり苦痛を感
じていない程の平均得点であった。これは，親の平均 年齢が 56.7 歳で, 子の平均年歯令は 27.16 歳ということ から，また，年齢と苦痛症状得点の負の相関から，己 の研究に参加した親たちが経験を積んだ養育者である ことが原因ではないかとしている。しかし，対照群と なる知的障害児を持たない親の苦痛症状得点が示され ていないので，本当に知的障害児を抱える親たちがあ まり苦痛を感じていないのか明確ではない。もしかし たら，使用した質問紙の性質上低く出た可能性はある。 このような研究においても, 対照群を持つことは非常 に大切であると思われる。また，この研究の主目的で ある NMRE と苦痛症状との関連は明らかにされたが, これは知的障害児を抱える親という特別なサンプルの みに見られるのか，海外の研究で明らかにされている ように一般のサンプルにも見られることなのか疑問が 残る。その意味でも, この研究においては対照群を含 めるべきであったと思う。

\section{教育実践に関する研究}

さまざまな教育実践がなされているが，ここでは論 文として発表された 3 つの研究と学会発表された 2 つ の研究を取りあげた。

植阪・光嶋（2013）は小学校 6 年生の国語のクラスに 俳句の鑑賞会を取り入れた授業の経過とその効果を報 告している。従来の国語の授業における俳句の指導は 名句の鑑賞が多く，俳句の代表的な解釈を知るだけの 授業になってしまいがちであるとの問題点を指摘した 上で，生徒に俳句を作らせ，それらの鑑賞会を実施し た取り組みが報告されている。この授業では，短歌・ 俳句の形式や歴史の理解から始まり, 創作のための技 法の学習や生徒が作った俳句の推敲過程（1事例だが）, 鑑賞会の様子などが述べられており，この取り組みが 大変素晴らしいものであったことが理解できる。最後 に考察として本取り組みの意義が述べられており, ど れも賛同できるものであるが，裏付けが弱いものもあ る。例えば，この授業が自己，他者，郷土というもの を再発見し，見つめ直す機会を子どもたちに提供した と述べられているが，これに関しては子どもたちから の感想などの裏付けがなく，実践者側の主観的な感想 であることも否めない。こうした授業の効果や意義に ついては，より客観的な裏付けが必要だと思われる。

吉野・山田・瀧ヶ平 (2014) の研究は音楽の授業に関 するものである。研究 1 では, 音楽鑑賞における演奏 者の映像を見せることが音楽的感情評価に影響するの かどうかを実験的手続きにより検討している。研究参 
加者は小学 5 年生 77 名と大学生 21 名で，それぞれを 音響のみ条件と映像付き条件に分けて音楽鑑賞を行 なった後, 尺度と自由記述により楽曲の感情価評定を 実施した。その結果，尺度による評定では映像の効果 は非常に限定的であり, 小学 5 年生も大学生も同じょ うな感情価評定であった。しかし，自由記述による評 定（記述数やカテゴリー）では，小学 5 年生と大学生で は全く逆の結果が示された。小学 5 年生では映像はマ イナスの効果, 大学生ではプラスの効果が見られ, こ れは 5 年生ではまだワーキングメモリの注意処理資源 が十分に発達していないからではないかとしている。 研究 2 では, 小学 4 年生の音楽の授業で，一つのクラ スでは必ず演奏者の映像を見せて楽曲を提示し（映像 付群)，もう一つのクラスでは主に音のみで楽曲を提 示し, 最後に映像付きで提示するというやり方（音中 心群)で音楽鑑賞の授業を行った。授業中の課題とし て「音楽の要素」や「連想した情景」など自由記述さ せ，楽曲や授業に対する興味度は質問紙で回答させて いる。その結果, 楽曲や授業に対する興味度は全体と してクラスによる違いは認められなかったが, 自由記 述課題の分析（記述量・カテゴリー）では，全体的に音中 心群の方がポジティブな結果であった。

著者らも言及しているが，測定が主に自由記述に基 づいているので，国語力に左右される可能性が大であ る。しかし，二つのクラスの国語力の査定はなされて いない。国語力だけでなく，学校の外で音楽の習い事 をしている生徒の人数やこれまでの音楽の成績など, 生徒の音楽についての背景などが二つのクラスで同じ なのかなども明確ではない。実践的調査であるので, ランダムに群分けできない分，二つのクラスの同質性 を明らかにすることは, 必須である。その点が欠けて いたことは残念である。しかし，音楽鑑賞における映 像の効果が小学生と大学生では違うこと, 小学生にお いては，音楽鑑賞に映像を付けることが必ずしも有意 義ではないことを示したことは音楽教育の分野で意義 があると考える。

道徳の授業での教育実践に関する研究が二つある。 一つは小学 6 年生を対象として, 仕事の社会貢献の側 面を強調した授業を行い，生徒の仕事に対する価値観 が変わるかどうかを調べたものである（三輪, 2014)。こ の研究では, 授業の前後に生徒に抽象的仕事観と具体 的仕事観について記述するという課題を与え，その内 容を分析した。結果，授業前には仕事の社会貢献につ いて述べていなかった生徒も授業後にはそれについて 述べる者が増加していた。もう一つの研究は小学 1 年
生を対象とした社会的スキル教育の実践である（吉田， 2014）。授業（著者は介入と呼んでいる）の前後で社会的入 キルについて質問紙調查を行った結果，介入前に社会 的スキルが低かった児童の社会スキル得点が上昇した ことが示された。両者とも学会発表のため, その要旨 からは，授業の内容の詳細を知ることができないので， コメントが難しいのであるが，どちらも授業（介入） を実施した直後に子どもの查定をしているが，フォ ローアップと言われる，もっと長期的な変化 (効果) を査定していない。特に, 価值観やスキルなどは一時 的変化であっては余り効果があるとは言えず，是非と もフォローアップデータを取って欲しいものである。

もう一つの実践研究は, 授業以外での教師の子ども との関わりに関する研究である。角南 (2013) は, 34 名の小学校教師に半構造化面接を行い, 授業時間以外 で子ぞものトラブルや問題行動に介入して, 子どもが 肯定的に変化した経験について語ってもらった。その データをグラウンデッド・セオリー・アプローチを用 いて分析し, 問題解決の教師の関わりとして「教師主 体の解決方法」「子ども主体の解決方法」「受容的関わ り」の 3 つに整理できることを示した。また, これら の分析から得られた下位カテゴリーなども含めて教師 の問題解決について 2 つのモデルを提示している。こ れらのモデルがこれまでの教師の子どもとの関わりを 確認することや今後問題場面に取り組む場合の手がか りとなるという角南の考えには賛同できる。特に, 子 どもとの関わりがよくわからない新任教師の場合など は，このモデルは参考になるのではないかと思う。今 後, 新任の教師を対象に, このモデルの有効性の検討 を試みて欲しいと思う。

\section{発達障害児に関する研究}

発達障害に関する研究は論文として発表されている ものが 3 篇で，全て自閉症児を対象としたものである。 学会発表では, 自閉症とは限らず, 発達障害児の学級 環境や教師の理解についての研究もあるが, ここでは, 論文との整合性を考え，発達障害児を観察した研究 1 篇を取り上げた。

狗巻 (2013) は, 自閉症児 (女児; 観察開始時 2 歳 10 ケ 月）と通園施設の保育者との相互作用を 3 年 4 ケ月に わたり観察 (録画) し, 分析している。この女児の共 同注意 (指さしの理解とその産出行動) の発達に従い観察 期間を 3 期に分け，それぞれの時期において，保育者 のどのような働きかけが自閉症児の受容反応を引き起 こすのかを分析した。ここでの保育者は特定の人では 
なく，この自閉症児に関わったのべ 9 名の保育者であ る。分析の結果, 3 つの時期を通して, 保育者の身体 的接近・接触や玩具などを用いた働きかけがジェス チャーや言葉を用いた働きかけよりも子どもの受容反 応をより多く引き起こしたことが明らかになった。ま た，子どもが興味や関心・要求を示す遊び道具を用い て働きかけたり (維持), 子どもの興味・関心を解釈し た上で新しい遊びに発展させるなどの働きかけ（発展） が子どもの受容反応を多く引き起こした。このような 保育者の働きかけと子どもの受容反応の関連は共同注 意の発達段階において質的な差が見られ, 発達に応じ た働きかけが重要であることが示唆された。ここで示 された自閉症児の受容反応を引き起こす保育者の働き かけは当たり前という結果であり，これらの働きかけ は自閉症児にかかわらず，定型発達児に対しても言え ることではないかと思われる。しかし，共同注意の発 達に応じて同じ働きかけが質的に違った反応を引き起 こしているという点は新しい知見であろう。

榊原（2013）は自身が関係支援の基礎を作るべく 1 年 6 ケ月間関与した自閉症児 (男児; 関与開始時 10 歳 5 ケ 月）との関わり（介入）から，関係性の変容を軸に自閉 症児の行動の変容を報告している。この事例において は, 関与開始後 6 ～ 8 ケ月で関与者がこの男児の愛着 対象者となり, それに伴い, こだわりの頻度が減少し たり，限定的ではあるが他者との関わりができるよう になったりなど, 男児の行動が変わったことが報告さ れている。この介入経験から, 著者は関与者が自閉症 児の愛着対象者として作用することの重要性を示して いる。また，その関与の仕方としては，対象児の不快 な情動を起こさせないようにし，対象児優先の養護的 な関わりを徹底したことが愛着形成へと導いたことが 述べられている。

狗巻 (2013) も榊原 (2013) も事例研究ではあるが, 両者とも自閉症児への関わり方に関して，その成功例 を示しており，自閉症児の対応について参考になる。 しかし，それぞれの対象児とその主要な養育者との関 係性については一切報告されていないので, 背景的な 要因が全く統制されていないことになる。特に, 榊原 （2013）は関与者が愛着対象になることの重要性を述 べているが，それには主要な養育者との愛着関係も影 響してくると考えられる。研究で述べられた介入だけ で十分なのか, 主要な養育者との安定的な愛着があっ てのことなのかなどは明確ではない。いずれにせよ， 両者とも事例研究であるため, 今後のデー夕の積み重 ねが必要である。
同じく自閉症児を研究対象としているが，李・田中 （2013）の研究は上述の 2 つ研究とはテーマが全く 異なっている。この研究は, 文字のない絵本を見て物 語を構成し, 聞き手に伝えるという課題(フィクショナ ルナラティブ）を与え，構成の側面と行為の側面におい て, 自閉症児 (26名; 8 19歳) と典型発達児 (32名; 7 〜19歳)を比較したものである。分析の結果, 自閉症 児は典型発達児よりもナラティブが短く, 登場人物や 場所，時間，行動状況，結果についての言及が少なく， 登場人物間の関係を捉えていないことが明らかとなっ た。行為の側面では, ナラティブを行う際に聞き手を 見る頻度数は小学生においてのみであるが, 自閉症児 は典型発達児よりも多かった。

前者の結果は従来言われている自閉症児の「心の理 論」の理解の弱さと関連していると述べられており, 別の側面 (フィクショナルナラティブ) からこれまでの知 見を裏付けている点で意義があると言える。後者の結 果は従来言われている自閉症児は聞き手の理解状態を 考慮しないということを支持しない結果であるとして いる。しかし，この研究では子どもがストーリーを話 す相手は大人であるということに注目したい。自閉症 児は療育などで大人との関わりが多く，そうした日常 生活が反映されて, 聞き手を頻繁に見ていたとも考え られる。自閉症児の社会性という意味では, 聞き手が 同年輩であることが重要であるので，聞き手が同年輩 の子どもである場合も同じ結果が得られるのか是非と も検証して欲しい。

自閉症児ではないが, 何らかの発達障害を有し, 支 援が必要な幼稚園児の他児との関わりを観察した研究 がある。司城（2014）は支援が必要な幼児 4 名を半年 間, 月 2 回の割合で参与観察を行い, 各対象児と他児 とのかかわり場面をエピソードとして取り上げ分析し た。特に, 関わりの変化に注目している。観察期間の 半年の間に, 遊びへの興味が増加し, 他児と関わりを 持つようになったり, 自分の思いと他者の思いの違い に気づいたりなどの変化が見られた例が報告されてい る。

上でも少し触れたが, 発達障害児の研究は介入など を行う療育上の成果に関する研究が多い中で, 発達障 害を有する子どもたちが実際に幼稚園ではどのように 過ごしているのかという研究は貴重であると思う。し かし, 著者はこの変化の過程はその子どもへの支援の 手がかりであると述べているが，具体的にはどのよう なことを意味しているのか理解しかねる。もつと具体 的にこの変化を捕らえて，どのような支援ができるの 
か述べて欲しかった。

\section{おわりに}

本稿では『教育心理学研究』にとどまらず, 『発達 心理学研究』『心理学研究』『Japanese Psychological Research』及び，『日本教育心理学会第 56 回総会発 表論文集』に発表された乳幼児・児童期の研究を概観 し，その中でも共通するテーマのものを拾い挙げ，そ れぞれの研究について議論した。筆者の専門外の分野 も多々あり，それぞれのコメントについては専門家に とっては的外れと思われるものもあるかもしれないが, その点については㧍許しいただきたい。

分野ごとに整理して研究を見てきたが，どれも興味 深い研究であった。特に, 違った分野として取り上げ た, 乳児の顔認知の研究と情動表出の研究がどちらも “怒り”を取り扱っていた点は興味深い。また，感情 理解の研究でも先行研究の結果と一致しなかったとし て“怒り”が出てきた。このことは多数ある感情の中 でも“怒り”は乳幼児・児童の世界において重要な感 情であることを示唆していると思う。この“怒り”を 共通項として分野の異なる研究が統合されるとより興 味深い, 意義のある研究に繋がるのではないかと思わ れる。また, 今回取り上げた研究では, 認知過程にお ける感情・情動の影響を考えさせるものが多かった。 例えば，分配行動における泣き顔，心の理論の誤信念 課題に驚きを導入する，ロールプレイイングによるマ インドリーディングの効果など。これらはより深い人 間理解に繋がる研究であり, 今後, この種の研究が増 えていくことを期待する。

本稿で取り上げた教育実践に関する論文 3 篇（角南, 2013 ; 植阪・光嶋, 2014 ; 吉野ら, 2014） は全て『教育心理学 研究』に揭載されたものである。このような教育実践 に関する研究は現場の教師の協力が不可欠であるが, この 3 篇を読むと，その協力体制が非常に良いことが うかがえる。教育実践に関する研究だけでなく, 子ど ものワーキングメモリを取り扱った研究も学校側の全 面的な協力があり，その協力体制の良さが論文に滲み 出ている。教育現場側としては，さまざまな行事が あったり，こなさなければならないカリキュラムが あったりなどで, 筆者も経験していることであるが, 研究への協力体制は必ずしも良いとは言えない。しか し, 今回これらの実践研究を読んで思ったことは, 研 究によって実践者側に得るものがある場合 (例えば, 生 徒汶する支援アプローチの提示など)，そしてそれが現場 側が求めているものである場合，全面的な協力体制が
得られるのだろうということである。また，そのよう な研究が真に求められている研究なのかもしれないと いうことである。しかし, 研究には即実践には結びつ かない基礎研究もあり, かつ, 幼稚園や学校の協力が 必要な場合も多々ある。そのような時には, 研究者が それらの基礎研究が学校現場においてもいかに重要で あるかについて現場側を説得する必要があるのだろう。

上述したように教育実践研究論文は全て『教育心理 学研究』に揭載されたものであるが, その他にどのよ うな研究が揭載されているのかというと, 今回取り上 げた研究では, 集団からの排除に関する研究と規範行 動の発達に関する研究で, どちらも児童期を対象とし ている。本稿では取り上げなかった研究も児童期を対 象とした研究であり, つまり, 過去 1 年間乳幼児期を 対象とした研究は全く揭載されなかったことになる。 本稿で取り上げた乳幼児を対象とした研究論文はほと んど『発達心理学研究』に揭載されたものである。乳 幼児の研究に関しては他に発表する場があるため, ほ とんどの研究者がそちらに投稿してしまうのかもしれ ないが，一方では『教育心理学研究』においては乳幼 児期の研究に関する投稿論文の不採択率が高いとも考 えられる。いずれにせよ, 今後, 『教育心理学研究』 により多くの乳幼児研究論文が揭載されることが望ま れる。

\section{引用文献}

Ainsworth, M. D. S., Blehar, M. C., Waters, E., \& Wall, S. (1978). Patterns of attachment : A psychological study of the strange situation. Hillsdale, NJ : Lawrence Erlbaum.

藤本浩一・山本利和・竹内伸宜・林 照子 (2014). 小 学生におけるワーキングメモリ訓練教材の効果の検 証一触覚版ジャンケンメモリー 日本教育心理学会 第 56 回総会発表論文集, 228 .

古見文一 (2013). ロールプレイ体験がマインド リーディングの活性化に及ぼす効果の発達的研究 発達心理学研究, 24, 308-317.

長谷川真里 (2014)。他者の多様性への寛容一児童 と青年における集団からの排除についての判断一 教育心理学研究, 62, 13-23.

東山薰 (2014)。 心的状態語の使用量から心の理 論を予測できるか? 一日本人母子における言語的相 互交渉からの検討一 日本教育心理学会第 56 回総 会発表論文集, 237 .

平川久美子 (2014). 幼児期から児童期にかけての 
情動の主張的表出の発達一怒りの表情表出の検討一 発達心理学研究, 25, 12-22.

Ichikawa, H., Tsuruhara, A., Kanazawa, S., \& Yamaguchi, M. K. (2013). Two-to three-month - old infants prefer moving face patterns to moving top-heavy patterns. Japanese Psychological Research, 55, 254-263.

Ichikawa, H., \& Yamaguchi, M. K. (2014). Infants' recognition of subtle anger facial expression. Japanese Psychological Research, 56, 15-23. 狗巻修司 (2013)。保育者のはたらきかけと自閉症 幼児の反応の縦断的検討一共同注意の発達との関連 から- 発達心理学研究, 24, 295-307.

石島このみ・根ヶ山光一 (2013). 乳児と母親のくす ぐり遊びに抢ける相互作用一文脈の共有を通じた意 図の読みとりー 発達心理学研究, 24, 326-336.

蒲谷慎介 (2013)。前言語期乳児のネガティブ情動 表出に対する母親の調律的応答一母親の内的作業モ デルおよび乳児の気質との関連— 発達心理学研 究, 24, 507-517.

蒲谷慎介 (2014)．前言語期乳児のネガティブ情動 表出に対する調律的応答と母親が抱く子ども表象と の関連 日本教育心理学会第 56 回総会発表論文集, 234.

加藤道代・黒澤 泰・神谷哲司 (2014). 夫婦ペアレ ンティング調整尺度作成と子育て時期による変化の 横断的検討 心理学研究, 84, 566-575.

近藤綾子・林 安紀子 (2014). 感情音声の理解と表 出の発達過程に関する研究 日本教育心理学会第 56 回総会発表論文集, 348.

Kono, K., \& Mearns, J. (2013). Distress of Japanese parents of children with intellectual disabilities : Correlations with age of parent and negative mood regulation expectancies. Japanese Psychological Research, 55, 358-365.

李 熙舶・田中真理 (2013). 自閉症スペクトラム障 害児におけるナラティブの特性一フィクショナルナ ラティブの構成と行為の側面に焦点を当てて一 発 達心理学研究, 24, 527-538.

眞榮城和美・梅崎高行 - 前川浩子 - 則定百合子 - 上長 然・田仲由佳・酒井 厚 (2014). 子ぞも期の社 会性の発達に関する縦断研究プロジェクト(6)一コン ピテンスの発達に影響を及ぼす養育態度ときょうだ い環境一 日本教育心理学会第 56 回総会発表論文 集, 519 .
枡田 恵 (2014). 幼児期における感情の理解と表 情表現の発達 発達心理学研究, 25, 151-161.

松本恵美 (2014)。览童期の友人関係に抢ける受容 性に関する研究一友人グループの排他性・他者との 関わり経験・性格特性との関連一 日本教育心理学 会第 56 回総会発表論文集, 525 .

三輪聡子（2014）。道徳授業を通した児童の価值観 の変化一「社会貢献」をテーマとした授業に着目し て一日本教育心理学会第 56 回総会発表論文集, 807.

本島優子 (2013). 家族の表出性と子どもの問題行 動一母親の抑うつ症状と敏感性を媒介として一心 理学研究, 84, 199-208.

西野泰代 (2014). 児童の「仲間外れ」を規定する 要因についての検討 日本教育心理学会第 56 回総 会発表論文集, 265 .

岡本依子・菅野幸恵・東海林麗香 - 高橋千枝 -八木下 （川田）暁子・青木弥生・石川あゆち・亀井美弥子・ 川田学・須田 治 (2014). 親はどのように乳児 とコミュニケートするか一前言語期の親子コミュニ ケーションにおける代弁の機能一 発達心理学研 究, 25, 23-37.

榊原久直 (2013)。自閉症児と特定の他者とのあい だにおける関係障碍の発達的変容(2)一主体的能力・ 障碍特性の変容と特定の他者との関連一 発達心理 学研究, 24, 273-283.

佐藤賢輔・実藤和佳子 (2013). 非合理的事象は幼児 の誤信念理解を促進するか一自己の驚きを手かがり とした心的状態の推論一 発達心理学研究, 24 , 348-357.

司城紀代美 （2014）。幼稚園に扔いて特別な支援を 必要とする子どもの他児とのかかわり 日本教育心 理学会第 56 回総会発表論文集, 306.

角南なおみ (2013). 子どもに肯定的変化を促す教 師の関わりの特徵一修正版グラウンデッド・セオ リー・アプローチによる仮説モデルの生成— 教育 心理学研究, 61, 323-339.

寺坂明子・下田芳幸 (2014). 小学生における学校で の怒りと社会的スキルの因果関係一交差遅れ効果モ デルによる検討一 日本教育心理学会第 56 回総会 発表論文集, 230 .

津及清美 (2013a)。 5 歳児の報酬分配に抢ける分配 方略と総報酬量及び分配パターンの関係 心理学研 究, 84, 274-280.

津々清美 (2013b)。 5 歳児の報酬分配における総報 
酬量と泣き顔の効果 心理学研究, 84, 354-364.

植阪友里・光嶋昭善 (2013). 創作と鑑賞の一体化を 取り入れた俳句指導一国語における新たな単元構成 の提案一 教育心理学研究, 61, 398-411.

梅崎高行 ・ 眞榮城和美・前川浩子・則定百合子・上長 然・田仲由佳・酒井彩子・酒井厚 (2014). 子 ども期の社会性の発達に関する縦断研究プロジェク ト(7)一子どもはいかにして習い事に出会いコンピテ ンスを育むのか一 日本教育心理学会第 56 回総会 発表論文集, 520 .

渡辺大介・湯澤正通・水口啓吾 (2014). 小学生によ る算数の作問におけるワーキングメモリの役割 発 達心理学研究, 25, 87-94.

山田洋平・小泉令三・中山和彦・宮原紀子 (2013). 小 中学生用規範行動自己評定尺度の開発と規範行動の 発達的変化 教育心理学研究, 61, 387-397.
吉田和樹 （2014）。道徳授業を利用した社会的スキ ル教育の実践一小学 1 年生を対象として一 日本教 育心理学会第 56 回総会発表論文集, 842 .

吉野 巌・山田健一・瀧ヶ平悠史 (2014)。音楽鑑賞 に打ける演奏者の映像の効果一音楽心理学研究に基 づく仮説の実践授業での検討一 教育心理学研究, 62, $143-155$.

湯澤正通・渡辺大介・水口啓吾・森田愛子・湯澤美紀 (2013). クラスでワーキングメモリの相対的に小 さい児童の授業態度と学習支援 発達心理学研究, 24, 380-390.

湯澤正通・齋藤 智・河村 暁 ・ 湯澤美紀 - 無藤 隆 (2014)。ワーキングメモリ理論と発達障害一環境 設定から学習・就業支援へ一 日本教育心理学会第 56 回総会発表論文集, 12-13. 